Curtain of Lies: The Battle over Truth in Stalinist Eastern Europe. By Melissa Feinberg. New York: Oxford University Press, 2017. xxii, 232 pp. Notes. Bibliography. Index. Illustrations. \$74.00, hard bound.

doi: 10.1017/slr.2018.317

This book is a provocative study of the "battle over truth" during the early Cold War: the efforts of communist regimes to monopolize public information space and efforts of western governments to penetrate the information Iron Curtain with alternative information by radio and leaflets.

Drawing on official publications and secret police archives, Melissa Feinberg demonstrates in Chapters 1-2 how communist regimes used the purge trials of Rudolf Slánský and other deposed leaders and the Soviet-inspired "peace campaign" to mobilize the citizenry to support the regimes and denounce the west. Citizens accepted Communist Party orthodoxies, Feinberg suggests, from a mixture of social alienation, belief in the new order, opportunism, cynicism, and above all fear.

Chapter 3 is devoted to the Crusade for Freedom, which sought to mobilize Americans in the anti-communist cause though appeals to patriotism and fear of Communism. Feinberg highlights the crusade of anti-communist hyperbole but errs in assuming that it guided Radio Free Europe (RFE) broadcasts. RFE officials at the time lamented the gap between the oversimplified anti-communist crusade language and their editorial policy. The chapter documents simplistic anti-communism of some pre-1953 RFE (and Voice of America [VOA]) commentaries. But its narrow focus ignores the rich menu of RFE programs that from the outset included hourly newscasts and features on suppressed national history and literature, religion, music, segments for communist activists, and more (documented for Poland in Lechosław Gawlikowski, Pracownicy Radia Wolna Europa: Biografie zwykłe i niezwykłe. Warsaw 2015, Annex 1).

Chapters 4-6 analyze interviews with east European refugees conducted by RFE ("Information Items") and VOA in the early 1950s, preserved in the National Archives and online at the Blinken Open Society Archives. Feinberg's book is welcome as the first comprehensive use of this "unique resource for historians" (xx). Acknowledging limitations of selection and recording, Feinberg uses the interviews to paint a nuanced picture of daily life in what western leaders and media commonly called "captive nations"-few east Europeans would dispute that characterizationand "slave labor camps"-which they were not. While there is considerable literature on daily life under communism in eastern Europe, Feinberg's exegesis of the interviews offers valuable depictions of how politically powerless people adapted to economic hardship and political repression in the "people's democracies." They queued for food, stole and smuggled state property, occasionally organized strikes, sought friendships in atomized society, feared informers, attended compulsory meetings, accepted some official "truth" or pretended to, migrated within themselves, relied on rumors, listened to western radios, and sometimes fanaticized about liberation.

Usefully mining the interviews for narratives and insights, Feinberg nevertheless overstates their importance for RFE broadcasting (their role in VOA broadcasting is not addressed). Even in the early 1950s, the interviews were one source of information about eastern Europe for RFE, along with comprehensive monitoring of communist media, information from western journalists, travelers and diplomats, and accounts of high-level defectors such as Józef Światło. The Items (as documented in archived organizational histories) were produced by émigré information staff who were not "analysts" or "researchers" (xxx)-RFE's research units were established later-but whose job was to provide information to émigré broadcasters and American policy officials who made their own judgments. While Feinberg's critique of some first-order "evaluation" comments is apt, those were not the views of RFE broadcasters or policy 
officials. My own judgment (as an RFE research analyst in the late 1960s) of the Items as a source of information was that some were golden, some interesting, and many useless.

Overestimating the importance of Items for broadcasting leads Feinberg to exaggerate a feed-back loop in which perceptions of broadcasters influenced the views of listeners, interviews with refugee listeners influenced perceptions of broadcasters, and so on. Research in RFE broadcast archives may clarify how much Information Items were used in specific broadcasts. Even so, while western radios (VOA and BBC from the outset, RFE after 1951) reached significant numbers of east Europeans in the early 1950s with information about their countries and the world unavailable in regime media, evidence is lacking that western broadcasts altered the mindset and vocabulary of listeners.

Readers will benefit from this book's nuanced examination of "lies" behind the Iron Curtain but will need to turn elsewhere for the successes and failures of countervailing western efforts to convey "truth" to Stalinist eastern Europe.

A. Ross JoHnson

Woodrow Wilson International Center for Scholars

\section{Broadcasting and National Imagination in Post-Communist Latvia: Defining the Nation, Defining Public Television. By Jānis Juzefovičs. Chicago: Intellect Books, 2017. 164 pp. Appendix. Bibliography. Index. \$50.00, paper. doi: 10.1017/slr.2018.318}

Jānis Juzefovičs' monograph Broadcasting and National Imagination in PostCommunist Latvia: Defining the Nation, Defining Public Television provides detailed insight into the media and TV viewing habits of ethnic Latvians and Russian speakers in Latvia. Juzefovičs's research angle and his methods allow him to go beyond generalized attributions and positions. His research approach of quota and snowball sampling to recruit participants for ten focus groups, as well as in-depth qualitative interviews with five families (including three generations) at their homes permit him to rebuke widespread accusations by ethnic Latvian politicians who tend to regard Russian speakers as completely stuck in the orbit of Russian propaganda. As Juzefovičs stresses, Latvia's Russian speakers are far more critical of the Russian media than they are given credit for.

Another important merit of this study is its focus on the diversity of Latvia's socalled "Russian-speaking population." Here, the monograph's appendix, in which Juzefovičs provides short overviews of the focus groups' participants as well as family profiles, is particularly revealing. The family profiles give the reader insight into the diversity of Latvian family life, where intermarriages between ethnic groups are common, and "Russian speakers" are by no means all ethnic Russians.

The monograph is organized into five chapters discussing the ways in which television viewing habits can help us understand the central question of national belonging in post-communist Latvia. Most of the research was conducted between October 2011 and July 2012, with emphasis on public television. While Juzefovičs assesses both viewing habits of ethnic Latvians and Russian speakers, a large focus of the study is the overarching question of national loyalty among Latvia's Russian speakers. The crisis in Ukraine has exacerbated the questioning of this group's loyalty by Latvia's nationalist politicians and also raised concerns among NATO partners. Yet, as Juzefovičs argues, even those (mostly elderly) Russian speakers who view Russia as their fatherland still see Latvia as their homeland, show interest in news from Latvia, 